\title{
THE RETURNS TO EDUCATION IN CHINA: EVIDENCE FROM THE 1986 COMPULSORY EDUCATION LAW
}

\author{
Hai Fang \\ Karen N. Eggleston \\ John A. Rizzo \\ Scott Rozelle \\ Richard J. Zeckhauser \\ Working Paper 18189 \\ http://www.nber.org/papers/w18189
NATIONAL BUREAU OF ECONOMIC RESEARCH
1050 Massachusetts Avenue
Cambridge, MA 02138
June 2012

The authors did not receive funding for their research. The views expressed herein are those of the authors and do not necessarily reflect the views of the National Bureau of Economic Research.

NBER working papers are circulated for discussion and comment purposes. They have not been peerreviewed or been subject to the review by the NBER Board of Directors that accompanies official NBER publications.

(C) 2012 by Hai Fang, Karen N. Eggleston, John A. Rizzo, Scott Rozelle, and Richard J. Zeckhauser. All rights reserved. Short sections of text, not to exceed two paragraphs, may be quoted without explicit permission provided that full credit, including $\odot$ notice, is given to the source. 
The Returns to Education in China: Evidence from the 1986 Compulsory Education Law Hai Fang, Karen N. Eggleston, John A. Rizzo, Scott Rozelle, and Richard J. Zeckhauser NBER Working Paper No. 18189

June 2012

JEL No. J31,O15,P52

\begin{abstract}
$\underline{\text { ABSTRACT }}$
As China transforms from a socialist planned economy to a market-oriented economy, its returns to education are expected to rise to meet those found in middle-income established market economies. This study employs a plausible instrument for education: the China Compulsory Education Law of 1986. We use differences among provinces in the dates of effective implementation of the compulsory education law to show that the law raised overall educational attainment in China by about 0.8 years of schooling. We then use this instrumental variable to control for the endogeneity of education and estimate the returns to an additional year of schooling in 1997-2006. Results imply that the overall returns to education are approximately 20 percent per year on average in contemporary China, fairly consistent with returns found in most industrialized economies. Returns differ among subpopulations; they increase after controlling for endogeneity of education.
\end{abstract}

\author{
Hai Fang \\ Department of Health Systems, \\ Management and Policy \\ University of Colorado Denver \\ 13001 E 17th Place, Campus Box B119 \\ Aurora, CO 80045 \\ hai.fang@ucdenver.edu \\ Karen N. Eggleston \\ Stanford University \\ Shorenstein Asia-Pacific Research Center \\ Encina Hall E311 \\ Stanford, CA 94305-6055 \\ karene@stanford.edu \\ John A. Rizzo \\ Stony Brook University \\ N-637 Social and Behavioral Sciences Bldg. \\ Stony Brook, NY 11794 \\ John.Rizzo@stonybrook.edu
}

Scott Rozelle

Stanford University

Freeman Spogli Institute for International Studies Encina Hall E407

Stanford, CA 94305-6055

rozelle@stanford.edu

Richard J. Zeckhauser

John F. Kennedy School of Government Harvard University

79 John F. Kennedy Street

Cambridge, MA 02138

and NBER

richard_zeckhauser@harvard.edu 


\section{Introduction}

Education plays an important role in determining labor-market performance, with bettereducated individuals generally receiving higher earnings. Educational levels of a labor force may also explain the overall economic growth in various countries (Becker 1964; Griliches 1970). In a seminal contribution, Mincer (1974) presented a human capital framework of education and earnings determination, spawning a large literature in which the natural logarithm of individual earnings — measured as annual, monthly, and/or hourly wages—is an additive function of education (in years of schooling or attainment of a high school diploma/college degree), working experience and other factors.

More recent studies have investigated the extent to which the correlation between educational attainment and earnings is causal (Card 1999). Education may well be endogenous, because, for example, higher inherent ability may lead individuals both to secure more education and to achieve higher earnings. To deal with the endogeneity, some studies have employed twins data to control for family background and inherent ability. Other studies have used various other measures, such as the institutional features of an educational system, to instrument for individual educational attainment. Several landmark studies that corrected for the endogeneity of education, using datasets from the 1960s and 1970s, concluded that one additional year of schooling in the US or Europe boosted earnings by 10 percent or more (Card 1999). ${ }^{1}$

China is an important country in which to study the relationship between education and earnings. Since the Reform and Opening Policy was instituted in 1978, China’s economic system has been transformed from a socialist planned economy to a predominantly market-oriented

\footnotetext{
${ }^{1}$ These studies generally found that the ability bias was smaller than had been previously expected (Becker 1964; Griliches 1977).
} 
economy. China’s economic growth has been unprecedented, lifting hundreds of millions of people out of poverty and making China the world's second largest economy by 2010 (World Bank 2011). One important reason that has been proposed for China's rapid economic growth is its relatively well-educated labor force, compared to those of other developing nations. According to the international dataset compiled by Barro and Lee (http://barrolee.com/), China’s population aged 15 and above had an average of 3.4 years of schooling in 1970, rising to 7.6 years by 2005—higher than values for Brazil, India or Indonesia. ${ }^{2}$ The returns to education in China may have increased during this economic transition.

Researchers have begun to examine the relationship between education and earnings using data from China. Some have addressed endogeneity by using family background or data on twins. Most studies find very low returns to education before the early 1990s (Fleisher and Wang 2005). State-owned enterprises and the collective economy remained dominant in the early reform era of the 1980s; competition for talent was limited, and remnants of the socialist redistributive economy still limited returns to education (Zhou 2000). Returns to education in China have increased substantially since the early 1990s (Heckman 2003). To our knowledge, however, only one previous study uses the implementation of compulsory schooling in China to address the endogeneity of educational attainment: Song (2012) estimates the labor market premium for completing primary education and finds that an additional year of schooling significantly reduces the probability of being in poverty.

We contribute to the literature in two ways. First, we use differences among provinces in the dates of effective implementation of the compulsory education law to identify the impact of

\footnotetext{
${ }^{2}$ In our data, the average number of years of schooling is 8.88 . This higher number compared to China's national average is expected, because our sample only includes individuals aged 45 or younger.
} 
the education law on years of schooling, both overall and among subgroups of the population. ${ }^{3}$ We show that the Compulsory Education Law of 1986 raised overall educational attainment in China (by about 0.8 years of schooling) during the 1997-2006 period, and that the impact varied systematically by location and by gender. Second, using the effective implementation dates of the law in different provinces as an instrumental variable, we assess the returns to one additional year of schooling in contemporary China. Our results imply that the overall returns to education are approximately 20 percent per year on average. This value is fairly consistent with, albeit slightly higher than, the returns found in most industrialized economies. Returns differ among subpopulations; they increase after controlling for the endogeneity of education.

The rest of this article is organized as follows. Section 2 reviews the previous literature, particularly focusing on research in China and on studies using institutional features of educational systems to control for endogeneity. Section 3 presents our estimation strategy. Section 4 details the data and Section 5 reports our results. Section 6 concludes with a discussion of how the 1986 China Compulsory Education Law affected education and how our estimates of returns to education compare to those of previous studies in China and in other countries.

\section{Previous Studies of Education's Effect on Earnings}

Card's (1999) excellent overall review of previous research on the returns to education focuses on methodological issues and on evidence from empirical studies available at that time, most of which used data from Western countries. This section reviews previous research related

\footnotetext{
${ }^{3}$ Song (2012) uses the same date of implementation for all provinces. Song focuses on variation in effectiveness of the law in raising years of schooling for older adolescents and in rural areas
} 
to the present study, including those studies using data from China as well as those using educational-system features as instrumental variables.

\section{Education and earnings in China}

The premise of compulsory education laws is that requiring a basic level of education improves the well-being of individuals and society, with one of the main channels being the monetary returns from additional years of schooling. Empirically demonstrating this presumed beneficial impact of such laws is important in the context of developing countries like China, where adolescents may find dropping out of school attractive given the opportunity cost of foregone earnings for unskilled labor, and families may doubt whether the government has their best interests in mind when passing the law. Moreover, previous studies have shown that returns to education were at first quite modest in China’s reform era, so that families may have been acting rationally by assuming that an additional year of schooling was not worth much.

The wage-compression policies and other institutions of the Maoist era in China suppressed returns to education. Fleisher and Wang (2005) examine the returns to education during the period of 1950 - 1994, and find a declining trend up to the Cultural Revolution in 1966. Those low returns are also found to persist for at least a decade after the inception of reforms in 1978. The average returns to one extra schooling year in China before the 1990s have been shown to be lower than those in the US, Europe, and other developed areas. Byron and Manaloto (1990), using a survey of 800 adults in Nanjing city, Jiangsu Province, find that the returns to an additional year of education in 1986 were less than 4 percent. Johnson and Chow (1997) also report that the Mincer-type returns to education were only 4.01 percent in rural China and 3.29 percent in urban China, using data from the 1988 Chinese Household Income Project. Z. Liu (1998) employs the same dataset to investigate how returns to education differ by level of 
work experience, finding 3 to 6 percent differences. Maurer-Fazio (1999) finds that the returns to education in China for young people were slightly higher than those for older people, but the overall returns were still found to be low before the early 1990s.

Low returns to education have also been found in other transitional economies, such as those of Bulgaria, Czech Republic, Romania, Russia, and Ukraine; but returns increased substantially after the transition to market-based economies in those countries (Fleisher 2005). As the state-owned enterprises and collective economy in China declined, especially after the early 1990s, the entire economic system transitioned from a centrally planned to a marketoriented economy. With wages increasingly determined by market forces, this economic transition presumably raised the returns to education in China as it did in other transition economies.

A large body of research suggests that during the post-reform period, productivity and efficiency became stronger predictors of individuals' earnings in China (Gustafsson and Li 2000; Knight and Song 2003). Because of education's link to productivity, the returns to education grew in both rural and urban areas. Yang (2004) analyzes panel data from Sichuan province for the period of 1985-1996 to investigate how education affected farmers' adjustments after economic policy reforms. Yang finds that in rural areas, schooling played a critical role in enabling farmers to respond efficiently to changing market conditions, predominantly by devoting more capital and labor to nonagricultural activities that yield higher returns. These findings are supported by the Zhang et al. (2002) study of participation in the labor force, entry into the labor market, and wages in rural Jiangsu households in 1988, 1992, and 1996. Zhang et al. (2002) find that rural individuals with more education are not only more likely to benefit from 
rising opportunities off the farm, but also to obtain better returns from on-farm activities compared to their less-educated counterparts.

Yang (2005) uses data from urban regions of the Chinese Household Income Project to compare returns to education in 1988 and 1995. He finds that the estimated rate of return to one additional year of schooling increased from 3.1 percent in 1988 to 5.1 percent in 1995.

Nevertheless, throughout the mid-1990s, wage differences by occupation, level of skill, and level of education remained very narrow in China compared to other transition economies (Psacharopolous and Patrinos 2004). Researchers have attempted to determine why during this period, when educated labor was scarce, the returns to education were not commensurate with its contribution to productivity. Based on panel data from 200 large rural enterprises in 10 provinces, Fleisher and Wang (2004) attribute the low private returns to education in China in the mid1990s to restrictions on worker mobility along with unexploited economies of scale in production among rural enterprises. These findings support the idea that returns to education reflect the extent to which wage rates are allowed to reflect differences in productivity (Fleisher and Wang 2005).

Beginning in the late 1990s, returns to education in China appear to have experienced a broad and sustained rise. Zhang et al. (2005) find returns to education increasing from 4 percent in 1988 to 10.2 percent in 2001. They observe that the rise in schooling returns through 2001 occurred across all groups of workers—-whether defined by gender, experience, region, or firm ownership—and was robust to adding other control variables. Appleton et al. (2005) use recall panel data from the China Household Income Project from 1988 to 2002 to examine the impact of worker characteristics on urban wages in China during a period of industry reform and ownership restructuring. Based on their cross-sectional Mincerian wage functions and fixed- 
effects panel estimates of changes in the wage structure over time, they conclude that the increase was greater in China (from 3 percent in 1988 to 5 percent in 2002) than in other (OECD) countries during this period. They attribute the sustained rise in returns to several potential demand-side factors, including a competitive labor market, skill-biased technological change, and increased trade. They also identify several supply-side explanations for the increased returns to schooling, including the liberalization of controls on migration, which increased the supply of predominantly low-skilled workers in urban areas and moderated the increase in their wages, thus raising the returns to education. Appleton et al. (2005) stress that, according to their fixedeffects estimation, the rise in the returns to education in the panel data cannot be explained by an increase in the quality of education.

The documented increase in returns to education since the 1990s in China underscores the potentially important role of the compulsory education law in improving welfare for those on the margin of not completing a middle school education. Even if such individuals correctly understood the returns to education at the time schooling decisions were made in the 1970s and 1980s, they may not have foreseen the rise in returns that would occur after they entered the labor market. Especially if returns to education diminish at higher levels, those individuals most tempted to drop out of school to take up low-skill factory wages are precisely the ones who would most benefit from compulsory education; their future earnings will be significantly higher with a few more years of education and will accumulate over their work life to far exceed the earnings they forego by staying in school.

$\mathrm{Li}$ (2003) argues that the returns to education for the more educated population in China, such as those with education beyond college, are higher than previous studies have shown. After correcting for reporting errors and ability heterogeneity, the estimated returns to education for a 
subsample of young workers are approximately 15 percent per year using data from the 1995

Chinese Household Income Project ( $\mathrm{Li}$ and Luo 2004). This estimated rate of return to education in China is roughly comparable to that in Western developed countries.

Heckman and Li (2004) study the returns to college education using data from the 2000 China Urban Household Investment and Expenditure Survey, also correcting for heterogeneity and selection bias. They find that a four-year college education raises annual income by 43 percent, arguing therefore that the returns to one additional year of college education average about 11 percent.

Not all studies find that the returns to education in China really increased dramatically. Li et al. (2005) find contradictory evidence. Using identical twins data from 5 cities in 2002, they find that a large portion of the observed returns to education reflect ability bias. After employing the twins fixed-effects estimation, the returns to education decrease from 8.4 percent to 2.7 percent; Li et al. (2005) argue that this low rate of return is due to the inefficient education system in China. Moreover, these results using twins data in China are at variance with much higher rates found by Ashenfelter and Rouse (1998) and Miller et al. (1995) using twins data in other countries. This suggests that the method of analysis does not explain the discrepancy. It also suggests that selective education according to ability may play a larger role in China than elsewhere.

\section{Finding an appropriate instrument for education}

Given the widely acknowledged endogeneity of educational attainment, it is important to find instruments to control for this phenomenon. Angrist and Krueger (1991) use the specific quarter of the year of an individual's birth as the instrument for his or her education, finding that individuals born earlier in the year have slightly less schooling than those born later in the same 
year. The likely explanation is that individuals born earlier in the year can attain the minimum legal age for leaving school at a lower grade. Their empirical analysis shows that the IV estimates of returns to education are slightly higher than those estimated by OLS (increasing from 7 percent to 10 percent), but these differences are not statistically significant. Staiger and Stock (1997) re-analyze Angrist and Krueger (1991)’s data, using limited-information maximum-likelihood methods, and find similar results.

Economists hypothesize that the distance to school may determine an individual's educational achievement, thus serving as a potential instrument. Growing up near a high school, college, or university may have a positive effect on an individual's educational attainment (Card 1995; Kane and Rouse 1993). The returns to education found from these school-proximity IV estimations are more than 50 percent higher than those using OLS.

Harmon and Walker (1995) study the returns to education using British data. The minimum age at which individuals were allowed to leave school in Britain was raised from 14 to 15 in 1947 and from 15 to 16 in 1973. Based on these institutional changes in the British schooling system, Harmon and Walker (1995) construct three cohort dummies: men born before 1932, men born between 1933 and 1957, and men born after 1957. Using these cohort dummies as instruments, Harmon and Walker find that returns to education based on OLS (6 percent) are underestimated compared to those in the two-stage least squares (2SLS) model (15 percent), producing results similar to those found by other studies using instrumental variables for education. 


\section{Estimation Strategy}

A change in China's laws enabled us to find an appropriate instrument for educational attainment. China’s Compulsory Education Law was passed on April 12, 1986 and officially went into effect on July 1, 1986. This was the first time that China used a law to specify educational policies for the entire country. However, provinces were allowed to have different effective dates for implementing the law, since the central authorities recognized that not all provinces would be ready to enforce the law immediately.

This law had several important features (China Ministry of Education 1986). First, 9 years of education became compulsory. Second, children were generally supposed to start their compulsory education at 6 years of age. Third, in principle, compulsory education was free of charge. Fourth, it became unlawful to employ children who are in their compulsory schooling years. Fifth, local governments were allowed to collect education taxes to finance compulsory education.

There are two significant differences between China’s Compulsory Education Law and its counterparts in the US and UK, which have been the focus of much of the previous literature on compulsory education. First, China’s per capita income at the time of implementation was much lower than recent per capita income in the US and UK. In addition, fiscal decentralization implemented around the same time reduced the central government's redistributive power, ${ }^{4}$

\footnotetext{
${ }^{4}$ In 1985, the Chinese Communist Party (CCP) issued the Decision of the Central Committee of the Chinese Communist Party on the Reform of the Educational System, devolving educational responsibility to lower levels of government. This reform increased inequality of funding between rural and urban schools, leading rural schools to diversify the sources of their funding. These diverse sources included school fees, levies, school- and communitygenerated revenues (Hannum 2003; Tsang 2000). Just one year later, the Compulsory Education Law officially made nine years of schooling compulsory throughout China, with implementation to be carried out in different
} 
leaving many local governments in poor provinces or regions with insufficient resources to implement the law fully (Hannum 2003; Zhang and Kanbur 2005). ${ }^{5}$ These factors suggest that the effectiveness of this program in achieving educational gains was almost certain to be uneven across China. Second, China's law stipulates 9 years of compulsory education instead of setting a minimum age for leaving school (although children cannot legally leave school if they are less than 15 years old). Those under 15 who had already left school by the law's effective date were required by the local education system to return to school until they turned 15. Local government and education officials are held responsible for school enrollment rates, and their promotions may be delayed as a punishment for low enrollment. However, the compulsory schooling law has been enforced unevenly in different parts of the country. Therefore, one of our main objectives is to use the actual effective date of implementation in each province to demonstrate that the law did impact educational attainment for those on the margin of completing 9 years of schooling. Then we use this impact as a method to estimate returns to education in contemporary China. Our estimation strategy exploits the fact that, as of the law's effective date, a Chinese child was supposed to have begun primary school when he or she reached 6 years of age. In this way, the child was supposed to complete his/her compulsory education when he or she reached 15 years of age. Children over 15 years old when the law became effective were not affected by the law and, thus, serve as our comparison group.

phases (Hawkins 2000). The reforms must be discussed together because, despite the compulsory education law mandating 9 years of education, children whose families could not pay some fees (such as textbooks) were not allowed to attend school (Brown and Park 2002).

${ }^{5}$ For example, all areas were expected to have primary education available for all students after 1986, but in reality, only 76 percent of counties had realized universal primary education by 1990 (Connelly and Zheng 2003). 
The staggered implementation of China's compulsory education law created a series of natural experiments. The effective date of the law's implementation in the province of residence will serve as our instrumental variable for estimating each individual's completed years of schooling. This obviates the problem of endogeneity due to unobservable variables that are correlated with both education and earnings (Card 1999). While an individual's inherent ability is generally unobservable, it should be expected to affect both education and earnings positively, as higher-ability individuals tend to obtain more education and higher incomes. If so, OLS estimation will overestimate the returns to schooling, although Griliches (1977) and Angrist and Krueger (1991) argue that the ability biases in OLS estimations are relatively small.

OLS may also underestimate returns to education, especially if there are diminishing marginal returns to education. If years of schooling are over-reported, the OLS estimate of the returns to education will be underestimated due to measurement error. In addition, Card (1999) suggests that the instrumental-variable estimates based on compulsory education laws may reveal higher returns to schooling than those estimated by OLS because individuals subject to compulsory education laws typically have marginal returns to schooling that are higher than average. Asymptotically unbiased estimates of the causal effect of schooling on earnings have been argued to be higher than those estimated by OLS (Card 1999; Staiger and Stock 1997). In fact, many of the previous studies using educational-system features as instruments report such higher returns--an increase of 30 percent or more compared to returns estimated with OLS without controlling for endogeneity (Card 1999).

As noted, China’s Compulsory Education Law serves as our instrument to address the endogeneity of years of schooling. We proceed as follows. First, following a standard Mincer 
(1974) analysis, we assume that the natural logarithm of individual earnings is a function of schooling years and other explanatory variables:

$$
\ln (E)=\beta_{0}+\beta_{1} S+\beta_{2} X+\varepsilon
$$

where

$\ln (E) \quad=\quad$ natural logarithm of annual earnings in 2006 Chinese currency (Renminbi Yuan);

$\begin{array}{lll}S & = & \text { school years completed; } \\ X & = & \text { a vector of other explanatory variables; } \\ \varepsilon & = & \text { a disturbance term; and } \\ \beta_{0}-\beta_{2} & = & \text { coefficients to be estimated. }\end{array}$

If education is endogenous, $\beta_{1}$ in Equation (1) may be biased and it might be possible to use an instrumental variable approach to account for the endogeneity. To be appropriate, the instrumental variable should be correlated with the years of schooling, but should not affect earnings except through the effect of years of schooling. The instrumental variable employed in this study is a binary variable indicating whether an individual was less than 15 years old on the law's effective date. As discussed above, the individual would not be affected by this compulsory education law if s/he was 15 years old or older when the law became effective in his or her home province. Thus, we construct a binary variable equal to 1 (treatment cohort) if the individual was less than 15 years old on the law's effective date, and equal to 0 otherwise (control cohort). Our hypothesis is that only individuals less than 15 years old on the law's effective date are potentially affected by China’s Compulsory Education Law of 1986.

The first stage estimates years of schooling as follows:

$$
S=\alpha_{0}+\alpha_{1} I V+\alpha_{2} X+\mu
$$


where

IV $\quad=\quad$ a dummy variable equal to 1 if the individual was less than 15 years old on the law's effective date.

$$
\begin{array}{lll}
\mu & = & \text { a disturbance term; and } \\
\alpha_{0}-\alpha_{2} & = & \text { coefficients to be estimated. }
\end{array}
$$

We pursue a two-stage least-squares estimation employing this instrumental variable. For this analysis, we define a treatment cohort of all individuals aged less than 15 years on the law's effective date in their home province, and a control cohort of all individuals aged 15 or older on the law's effective date. One basic strategy is to contrast the outcomes for these overall treatment and control cohorts. This strategy is similar to those used by Angrist and Krueger (1991) and Harmon and Walker (1995).

One concern with our instrumental variable strategy is that a time trend may also be affecting individual earnings. If this is true, it is possible that the treatment cohort may have higher earnings and/or better education than the control cohort simply because they came along later. Such a concern would be grave for one of two reasons: a.) if the study data spanned a long time period; or b.) if the country experienced rapid economic growth during this period. Since our time period is relatively short, “a” is not really a concern.

However, China’s economy was growing rapidly during this period. To overcome this potential concern, we employ a more refined estimation procedure that defines treatment and control groups that are similar in age. Specifically, we compare a two-year treatment cohort (aged 13 and 14 on the law's effective date) to a two-year control cohort (aged 15 and 16 on the law's effective date). Within these two-year treatment and control cohorts, the time trends that we are concerned about will, by definition, be much smaller than for the overall sample. We 
choose two years for the following reasons. First, one year's data would provide a smaller sample size. Second, our approach enables us to test on either side of the dividing line, to see whether there is considerable growth in education between two successive years in either the two-year treatment cohort or the two-year control cohort. Consistent with the latter approach, we test year dummies within these two-year treatment and two-year control cohorts.

If China's Compulsory Education Law is a valid instrument for educational attainment, the two-year treatment cohort will have significantly higher educational attainment than the twoyear control cohort. However, a dummy variable for the second year within each of these twoyear treatment or control cohorts will not explain differences in schooling, even if a year-trend effect exists. In other words, a dummy variable for being age 16 (the second year of the two-year control cohort) should not affect schooling within the control cohort; similarly, a dummy variable for being age 14 of the two-year treatment cohort should not affect schooling within the treatment cohort.

A further robustness check involves testing for the effects of "placebo laws," counterfactually assuming the law was enforced two years earlier or two years later than it was actually enforced in a given province. If our instrument is valid, we should find no effects for these two different hypothetical law years. Any differences would only reflect a time trend, and these counterfactual year dates should fail tests for being a valid instrument for education. In the two-stage least-squares estimation, we also employ an exclusion test of the instrumental variable to identify whether the instrumental variable has no direct effect on the earnings measure when controlling for all other explanatory variables. 


\section{Data and Variables}

We use data from the China Health and Nutrition Survey (CHNS), which is maintained at the Carolina Population Center of the University of North Carolina at Chapel Hill. The CHNS is collected by the Carolina Population Center and the National Institute of Nutrition and Food Safety at the Chinese Center for Disease Control and Prevention. Our study uses four recent waves of data collected in 1997, 2000, 2004, and 2006. We use four waves of data to ensure that we have a large enough sample of individuals affected by the 1986 China Compulsory Education Law, particularly for the models using two-year restricted cohorts.

Mainland China consists of 32 province-level administrative units. The CHNS data were collected from 9 provinces: Heilongjiang, Liaoning, Jiangsu, Shandong, Henan, Hubei, Hunan, Guangxi, and Guizhou. These 9 provinces account for approximately 44 percent of the Chinese population. They vary substantially in geography, economic development, public resources, and health indicators, with greater wealth and development in the eastern coastal provinces. Heilongjiang and Liaoning are two heavily industrialized provinces in northeastern China. Jiangsu and Shandong are two lightly industrialized provinces in eastern China. Henan, Hubei, and Hunan are three agricultural provinces in central China, and Guangxi and Guizhou are relatively underdeveloped southwestern provinces.

The CHNS employed sophisticated sampling techniques. A multistage, random cluster process was used to draw the sample surveyed in each of the provinces. Counties in the 9 provinces were stratified by income (low, middle, and high), and a weighted sampling scheme was used to select randomly 4 counties within each province. In addition, the provincial capital and a lower-income city were selected when feasible. Villages within the counties, and urban and suburban neighborhoods within the cities, were chosen at random. 
The effective dates of the China Compulsory Education Law differed by province, as provincial governments had first to enact specific regulations (equivalent to provincial laws) before the law was enforced in that province. For the 9 provinces in the CHNS data, the actual effective dates are July 1, 1986 in Heilongjiang and Liaoning; September 9, 1986 in Jiangsu; September 12, 1986 in Shandong; October 1, 1986 in Henan; March 1, 1987 in Hubei; January 1, 1988 in Guizhou; and September 1, 1991 in Hunan and Guangxi. Because the official effective date of China’s compulsory education law as dictated by the central government was July 1, 1986 and schools in China have summer break in July and August, we use September 1 as the effective date if the provincial effective date was within summer break.

Migration raises another issue: if an individual permanently migrates to another province after completing compulsory education, the schooling province and household registration province for that same individual in CHNS survey data may be different. In reality, however, much of China's large migrant workforce only migrates temporarily and/or migrates from rural to urban areas within the same province. Interprovincial migration has been relatively limited in China and has been strictly controlled by the government at various levels, using the household registration (hukou) system. ${ }^{6}$ Previous studies show that interprovincial migration was only 3 percent between 1990 and 2000 (Johnson 2003; Fan 2005), so interprovincial migration is unlikely to invalidate our instrumental variable.

Another consideration is how to define a good comparison group. Cohorts born in the pre-Mao and early Mao era, or during the Great Leap Famine (1959-1960), may not be

\footnotetext{
${ }^{6}$ For example, urban social safety net policies only cover households registered as urban in that locality, and children of migrant workers usually cannot attend urban public schools. During the period of our study, children of migrants sometimes attended schools specifically set up for migrants, but such children have always been required to return to their household registration locality to take the tests for progression to higher levels of schooling.
} 
appropriate, given the very different social and economic conditions of their childhoods compared to contemporary China. In particular, the schooling of those born in the 1950s was severely impaired by the political turmoil of the Cultural Revolution (1966-1976). During that decade, many high schools and colleges were closed, and millions of junior high school graduates in urban areas were required to work in rural and mountainous areas. Students in primary and middle school were less likely to be affected. If we include those who were affected by China's Cultural Revolution, their actual educational attainment may be lower than those who are younger, despite official statistics indicating otherwise. Therefore, we include in our sample only those born in 1961 or later, so that they were younger than 15 by the end of the Cultural Revolution in 1976. This conservative strategy avoids a potential downward bias in schooling within the control group due to political disruption. ${ }^{7}$

Our dependent variable is the natural logarithm of total individual yearly earnings, which include annual income from all sources collected in the CHNS data: wages; income from business, farming, gardening, fishing, and/or raising livestock; ${ }^{8}$ and retirement and nonretirement transfers. Because earnings measures are right-skewed, we define our dependent variable as the natural logarithm of yearly earnings (Mincer 1974). The key explanatory variable is the number of years of schooling that an individual has completed. Students currently studying in school are excluded from our study sample because they do not have earnings. Our

\footnotetext{
${ }^{7}$ Other studies also have this potential problem of large political disruptions in schooling; the Harmon and Walker (1995) study, for example, includes students impacted by World War II.

${ }^{8}$ These incomes from business, farming, gardening, fishing, and/or raising livestock are often at the household level and these economic activities are run by the entire household. CHNS allocates these household-based incomes to individual members according to the hours that individuals spend on those economic activities as a proportion of the total hours spent by the entire household for the same type of economic activities.
} 
multivariate framework controls for other explanatory variables, such as age, gender, ethnic minority, marital status, urban residency, self-reported health status, ${ }^{9}$ province, and CHNS survey wave. We use data from 1997 to 2006 to enlarge our sample size. ${ }^{10}$

\section{Descriptive statistics}

We employ two levels of analysis. The first level comprises all the people who were born in 1961 or later as the "All” sample. The second level moves to our restricted cohorts of people aged $13,14,15$, and 16 by the law's effective dates in the various provinces. The restricted cohorts are more homogenous, and the year-trend effects are minimal. Table 1 shows summary statistics for the first level of analysis for three groups: the entire sample (“All”), the control cohort (aged 15 or older by the law’s effective date), and the treatment cohort (less than 15 years old on the law's effective date). The descriptive statistics in Table 1 show that the average educational attainment of individuals in the treatment cohort is indeed higher than that of the control cohort (9.28 vs. 8.66) years, a difference that is statistically significant at the 1 percent level. A comparison of the raw difference in income is more difficult to interpret, since multiple forces impact individual income, including age and experience in the labor force. Since the treatment cohort is, by definition, younger and came along later than the control cohort, average

\footnotetext{
${ }^{9}$ Health has been found to affect income significantly in China (Liu et al. 2008), but our estimation without controlling for self-reported health status shows a similar trend as reported in the paper. The results without controlling for health are available from the authors upon request.

${ }^{10}$ Earlier data from CHNS 1989-1993 are not used in this study. Very few observations that encompassed the period of educational reform were included in that earlier data, since the Chinese Compulsory Education Law was not enforced until 1986. CHNS is an unbalanced panel data set, so the same individual may appear in more than one wave of the data. We have used a sample weight variable in the estimation to control for this issue as weighted estimation.
} 
earnings may be higher or lower depending on whether greater age outweighs income growth over time. In our data, the treatment cohort is approximately ten years younger than the control cohort, and this factor may work to reduce the average yearly earnings of the treatment cohort relative to the control.

\section{(Insert Table 1)}

\section{Results}

Table 2 shows results from the first stage of the two-stage least squares (2SLS) estimation. In the first column, the estimated coefficient of 0.79 on the dummy variable for being less than 15 years old by the law's effective date is statistically significant in the entire sample. Next, we study the four-year period spanning immediately before and after implementation of the compulsory education law (ages 13-16 by the law's effective date in a given province). When we study these selected control and treatment cohorts (the second column), the estimated coefficient on the dummy variable for treatment year is 0.66 and is statistically significant. To demonstrate that the treatment dummy does not merely proxy for year trends in education, columns 3 and 4 show that a year dummy does not affect educational attainment either within the two-year control cohort or within the two-year treatment cohort. A number of statistical tests of our instrument also reveal that the instrument is valid in terms of the excluded-instrument test, under-identification test, weak-identification test, and weak-instrument-robustness test. Our results suggest that the Compulsory Education Law of 1986 did significantly raise educational attainment and that these changes in schooling do not simply reflect a time trend toward more schooling for younger cohorts.

(Insert Table 2) 
Researchers are also interested in knowing the differential impact of compulsory schooling by gender, urban versus rural residence, and inland versus coastal location. For example, a stronger impact for girls might be expected, since lower overall schooling implies that more girls than boys would be on the margin of being impacted by the law. Whether compulsory schooling would raise schooling more in rural or urban areas is less clear, given several countervailing forces. First, urban areas are more likely to have enforced the law strictly on the legally effective date. Second, given their higher quality of schools, families in urban areas may have been more likely to comply, thus reducing the costs of enforcement compared to rural areas. However, rural areas are home to more children on the margin of dropping out of junior high school, and therefore the requirement of 9 years of education would have a higher impact in rural areas for a given enforcement level. A similar set of forces may have shaped the effectiveness of the compulsory education law among inland and coastal provinces, with enforcement in the less-developed inland provinces more likely compromised by lower-quality governance (higher enforcement costs), lower-quality schools, and more limited local opportunities for returns to education.

As Table 3 shows, the OLS estimation of the first stage regression using our instrumental variable finds that the marginal effects of the compulsory education law are highly significant and positive for each of the different subsamples. The various tests of our instrumental variable shown in Table 3 ensure its validity. We find that the law increases years of schooling for all subgroups, but most strongly for girls (1.17 years) rather than for boys ( 0.4 years). The law also increases years slightly more strongly in rural (compared to urban) and coastal (compared to inland) areas. 


\section{(Insert Table 3)}

We turn next to estimating the returns to education. Table 4 shows that without addressing endogeneity (that is, using OLS) in the entire sample, one additional year of schooling increases individual annual earnings by 9 percent. Using our IV in 2SLS, the marginal effect becomes 20 percent. This result of higher estimated returns when controlling for endogeneity is consistent with previous studies that use the features of schooling systems as instruments (Angrist and Krueger 1991; Card 1999; Harmon and Walker 1995). The magnitude-20 percent estimated returns--is slightly higher than the magnitudes found in those previous studies, which focus on more developed countries. ${ }^{11}$

\section{(Insert Table 4)}

The results in Table 5 show that our instrument remains valid even when using four years of data, as we did with the two-year control cohort and two-year treatment cohort. For this more narrowly defined sample, the marginal effect is 9 percent with OLS (significant at the 1 percent level) and 26 percent using 2SLS (also significant at the 1 percent level). Further validation of our identification strategy comes from the fact that the 2SLS coefficients are not statistically significant either within the two-year control cohort or within the two-year treatment cohort. This result is not surprising, given that the series of statistical tests reported in Table 2 reveals that a year dummy within these two-year control or two-year treatment cohorts is not a good instrument for educational attainment.

\section{(Insert Table 5)}

\footnotetext{
${ }^{11}$ Our estimates also reveal that controlling for endogeneity of education reduces the returns to being male and the returns to age/experience, although both are still quite significant in explaining higher earnings. Controlling for endogeneity also reduces the roles of health, province, and wave of data in explaining variation in earnings.
} 
Table 6 shows the marginal effect of one extra year of schooling on earnings. The marginal effect is 9 percent for both females and males using OLS. However, when estimated with 2SLS, the marginal effect for males increases to 51 percent, while that for females remains essentially unchanged. This large marginal effect may be related to the relative weakness of our instrument for males, as shown in Table 3.

\section{(Insert Table 6)}

In the OLS estimation, the returns to an additional year of schooling (8-9 percent) are the same in rural and urban areas, but after correcting for the endogeneity of years of schooling in the two-stage least squares estimation, the marginal effect rises to 18 percent for rural areas and only 14 percent for urban areas.

Turning to inland and coastal differences, we find that with OLS estimation, the marginal effect of one additional year of schooling is 9 percent for both inland provinces and coastal provinces. After addressing endogeneity with 2SLS, the marginal effect for coastal provinces increases to 37 percent, and that for inland provinces moves only slightly higher to 12 percent.

As a final sensitivity test, we examine two "placebo" (or hypothetical) law years, one prior to the actual compulsory education law and one after the law went into effect. By definition, the law was not implemented in these "placebo" years. For example, in no province was the law implemented in 1984. If our results are truly capturing the impact of the compulsory education law rather than a time trend, results should not also appear for a placebo year like 1984 . We first make the counterfactual assumption of implementation two years after the actual effective date for a given province. To do so, we examine a sample of individuals aged 15 and 16 on the law's actual effective date (Cohort 1) compared to a sample aged 17 and 18 on the law’s actual effective date. We find that a dummy variable for Cohort 2 does not affect educational 
attainment. Thus, a placebo law of two years earlier shows no significant effect. These results are reported in Table 7.

\section{(Insert Table 7)}

Similarly, we study a sample of individuals whose birth dates make them the first four years of students after the compulsory education law went into effect. These two cohorts of

youths include those aged 11 and 12 by the law’s effective date (Cohort 3) and those aged 13 and 14 by the law's effective date (Cohort 4). We find that a dummy variable for being in Cohort 4 affects education, but its coefficient is only 0.25. In addition, this instrument cannot pass the weak-instrument test, and the F statistic in the first stage is only 3.65 (much less than 10). Thus, although there does appear to be a year trend of increasing education within the two two-year cohorts immediately following the compulsory education law, an instrument based on being born in Cohort 4 is not valid. These placebo-law results--employing the same strategy as we did with our main results--show no significant impact of a counterfactual "law" either two years earlier or two years later than the actual first enforcement of the law. These results offer reassurance that our 2SLS results in Table 4 are capturing the impact of the actual compulsory education law.

\section{Discussion and Conclusion}

In the early 1960s one-third of Chinese were illiterate; now, fewer than 5 percent are (Peng 2011). In 1986 China’s central government passed a law requiring 9 years of education, and over the subsequent several years, provincial authorities began enforcing compulsory education in their localities. By 2010 China had 8,930 college graduates for every 100,000 people, with about 120 million having a college degree (Peng 2011). A comparatively educated labor force has been singled out as one important determinant of China’s unprecedented economic growth since the early 1980s. Yet, to date, no study has definitively shown whether the 
1986 compulsory education law played a causal role in China’s substantial increases in education, and whether the law benefited the individuals whom it compelled to stay in school, by yielding significant returns at the individual level. China's case also has broad implications for understanding the role of education in economic development and whether returns to education in a globalized world have converged toward similar levels.

In this study, we test whether the China Compulsory Education Law of 1986 raised educational attainment overall and in specific subpopulations. We then use the phased implementation of compulsory education across provinces as an instrument to estimate the returns to each additional year of schooling in contemporary China.

Our first main finding is that the law increased years of schooling by about 0.8 years on average, with slightly higher effects for rural and coastal areas, compared to urban or inland areas. These results may reflect the interplay of many factors, including the fact that enforcement of the law was probably least stringent in precisely those regions where the most people could benefit from such a law, that is, in less developed rural areas. The compulsory education law also increased years of schooling strikingly more for girls (1.17 years) than for boys (0.4 years).

Our second main result is that, as China transformed from a socialist planned economy to a market-oriented economy, its returns to education rose to meet those found in established market economies around the globe. Using the effective implementation date of the law in each province as an instrumental variable to control for endogeneity of schooling, we estimate that that the overall returns to schooling are approximately 20 percent for one additional year of schooling. This estimate is fairly comparable with - albeit somewhat higher than - the doubledigit returns found in most Western countries. These higher returns might be expected in a rapidly growing economy when there are diminishing returns to additional years of schooling; 
those affected by the compulsory schooling law are on the lower range of the schooling distribution and have higher-than-average returns to an additional year of schooling (Card 1999). Because of the law, those individuals are better equipped to move from unskilled to semi-skilled jobs as the economy develops. ${ }^{12}$

We also report results exploring how returns to education vary by gender, by urban vs. rural regions, and by inland vs. coastal provinces. We find that the estimated returns to schooling are significantly higher for men (50 percent) than for women (10 percent), and higher for individuals from rural and coastal areas than from other areas of China.

The striking gender difference in returns could arise from several factors. With more boys than girls already completing middle school education before the law, the first stage impact was lower for boys than girls. The boys affected by the compulsory schooling law were even lower in the range of the male schooling distribution than the girls were in the female schooling distribution. The men would therefore be expected to have higher-than-average returns to an additional year of schooling. Higher labor market returns to schooling for men probably are also related to lingering differences in the occupations and wages for women relative to men in China, consistent with existing literature (P. Liu et al. 2000; Rozelle et al. 2002) showing a gender gap

\footnotetext{
${ }^{12}$ Our estimate also is approximately double the returns to schooling estimated by OLS without controlling for endogeneity. Previous studies have often shown that the returns to education by IV estimation are larger than those by OLS estimation, and the results in the present study are consistent with this literature. For example, Trostel et al. (2002) estimate the economic returns to education for 28 countries. They find that correcting for the endogeneity of education using various instrumental variables increases the estimated returns to education by more than 20 percent, compared to those estimated by OLS.
} 
in employment opportunities and earnings. ${ }^{13}$ Although higher returns might therefore be expected for men, the large magnitude of the difference we found suggests that our instrumental variable approach has limits for estimating the more generalizable difference in returns to education by gender, which merits further research.

Highly educated people in rural China are scarcer than in urban China, so the returns to education would be expected to be higher in the rural areas. We estimate that the higher rural returns are concentrated mostly in coastal rather than inland rural areas. These higher returns for coastal provinces may reflect overall "better governance," including better enforcement of the law (consistent with the first-stage results in Table 3), as well as better transport infrastructure and more vibrant off-farm economies that would facilitate employment for those with sufficient schooling. Lack of any statistically significant returns to education in inland provinces may arise because the inland areas suffer from lower-quality schools (a factor not evaluated here). Moreover, with constraints on inter-provincial permanent migration, the increase in population with junior high school education could have begun to saturate the market for low-skill industrial workers in inland areas, depressing the wages relative to more skilled (senior high school and above) workers. Further study, with controls for school quality, should investigate this geographic difference in returns to education and our conjectured explanations.

\footnotetext{
${ }^{13}$ Women's overall employment rates declined in the reform era (compared to very high female labor-force participation in the Mao era). In addition, our sample is relatively young, so that the women are concentrated in their child-bearing years and may suffer an earnings loss compared to the control group of women who are older and mostly past their child-bearing years. (Recall that the average age of the treatment group is 24.7 years old, compared to 35.6 for the control cohort; see Table 1.) A larger allocation of family business earnings to men than to women could also be playing a role in the large gender difference in returns.
} 
We employed numerous sensitivity analyses to check the robustness of our results. Nevertheless, several limitations of the present study should be noted. First, we employ a threshold date as the instrument for education, but we know that not all regions within the same provinces implemented the new law equally and immediately, and we cannot completely rule out a year-trend effect. Second, the China Health and Nutrition Survey data only cover 9 provinces, and thus is not nationally representative. Our results do not generalize to all of China. Third, the cohorts impacted by the 1986 China Compulsory Education Law are still relatively young, and we are unable to look at the returns to education over a lifetime of earnings. Fourth, the treatment and control cohorts are not homogenous in terms of age, although our two-year restricted cohorts were employed to minimize this limitation. Fifth, the CHNS data precludes separately identifying migrants from rural to urban areas (either temporary or permanent); China’s urbanization has been rapid, and the returns to education for migrant workers may be different. Moreover, some of their gains may be due to migration to higher-wage areas, as a byproduct of seeking education, rather than due to the education itself. Sixth, the power of our instrumental variable is probably reduced by the uneven implementation of the compulsory schooling laws.

The present study provides updated results to the literature regarding returns to education in China by employing data collected between 1997 and 2006. Most previous studies use data from before $1995{ }^{14}$ The returns to education in China have increased from less than 5 percent prior to the early 1990s to about 20 percent during the period of 1997 to 2006 . The updated returns to education in China reflect a significant increase in returns, converging to levels comparable to or exceeding those in Western countries. As China's economy has transitioned

\footnotetext{
${ }^{14}$ Heckman and Li (2004) use data from 2000, and Zhang et al. (2005) use data from 2001; but the data in the present study covers multiple years from 1997 to 2006.
} 
from its previous socialist redistributive institutions and become much more deeply integrated into the global market, equivalent returns to education are now being realized.

\section{Acknowledgments:}

We thank Ang Sun and participants in the Sixteenth International Economics Association Congress on July 4-8, 2011 in Beijing for helpful comments on an earlier draft.

\section{References}

Angrist, J.D., Krueger, A.B., 1991. Does compulsory school attendance affect schooling and earnings? Quarterly Journal of Economics. 106, 979-1014.

Appleton, S., Song, L., Xia, Q., 2005. Has China crossed the river? The evolution of wage structure in urban China during reform and retrenchment. Journal of Comparative Economics. 33, 644-663.

Ashenfelter, O., Rouse, C.E., 1998. Income, schooling and ability: evidence from a new sample of identical twins. Quarterly Journal of Economics, 113(1), 253-284.

Becker, G.S., 1964. Human Capital: A Theoretical and Empirical Analysis, with Special Reference to Education. Columbia University Press: New York.

Brown, P. H., Park, A., 2002. Education and poverty in rural China. Economics of Education Review. 21(6), 523-541.

Byron, R.P., Manaloto, E.Q., 1990. Returns to education in China. Economic Development and Cultural Change. 38(4), 783-796.

Card, D., 1995. Using geographic variation in college proximity to estimate the return to schooling. In Christofides LN, Grant Kenneth, Swidinsky R eds. Aspects of Labour Market Behaviour: Essays in Honour of John Vanderkamp. University of Toronto Press: Toronto Canada, pp. 201-222.

Card, D., 1999. The causal effect of education on earnings. Handbook of Labor Economics, Edited by Ashenfelter O and Card D. Volume 3 (Part 1): 1801-1863. 
China Ministry of Education. 1986. Compulsory Education Law of People’s Republic of China 1986. http://www.edu.cn/20060303/3176577.shtml, accessed on 04/02/2011.

Connelly, R., Zheng, Z., 2003. Determinants of school enrollment and completion of 10 to 18 year olds in China. Economics of Education Review. 22(4), 379-388.

Fan, C.C., 2005. Interprovincial migration, population redistribution, and regional development in China: 1990 and 2000 Census comparisons. The Professional Geographer. 57(2), 295-311.

Fleisher, B.M., 2005. Returns to schooling in transition: the Chinese, European, and Russian experiences. Journal of Comparative Economics. 33(2), 223-226.

Fleisher, B.M., Sabirianova, K., Wang X., 2005. Returns to skills and the speed of reforms: Evidence from Central and Eastern Europe, China, and Russia. Journal of Comparative Economics. 33, 351370.

Fleisher, B.M., Wang, X., 2004. Skill differentials, return to schooling, and market segmentation in a transition economy: the case of Mainland China. Journal of Development Economics. 73, 315- 328.

Fleisher, B.M., Wang, X., 2005. Returns to schooling in China under planning and reform. Journal of Comparative Economics. 33(2): 265-277.

Griliches, Z., 1970. Notes on the role of education in production functions and growth accounting. In Hansen L ed. Studies in Income and Wealth, Vol 35. Columbia University Press: New York.

Griliches, Z., 1977. Estimating the returns to schooling: some econometric problems. Econometrica. 45: 1-22.

Gustafsson, B. Li, S., 2000. Economic transformation and the gender earnings gap in urban China. Journal of Population Economics. 13, 305-329.

Gustafsson, B.,Li, S., 2001. The Anatomy of Rising Earnings Inequality in Urban China. Journal of Comparative Economics. 29, 118-135.

Hannum, E., 2003. Poverty and basic education in rural China: Villages, households, and girls' and boys' enrollment,. Comparative Education Review. 47(2), 141-159. 
Harmon, C., Walker, I., 1995. Estimates of the economic return to schooling for the United Kingdom. American Economic Review. 85: 1278-1286.

Hawkins, J.N., 2000. Centralization, decentralization, recentralization--educational reform in China. Journal of Educational Administration. 38(5), 442-455.

Heckman, J.J., 2003. China’s investment in human capital. Economic Development and Cultural Change. 51(4), 795-804.

Heckman, J.J., Li, X., 2004. Selection bias, comparative advantage and heterogeneous returns to education: evidence from China in 2000. Pacific Economic Review. 9(3), 155-171.

Johnson, D.G., 2003. Provincial migration in China in the 1990s. China Economic Review. 14(1), 22-31.

Johnson, E.N., Chow, G.C., 1997. Rates of return to schooling in China. Pacific Economic Review. 2(2), 101-113.

Kane, T.J., Rouse, C.E., 1993. Labor market returns to two- and four-year colleges: is a credit a credit and do degrees matter? NBER Working Paper no. 4268.

Knight, J., Song, L., 2003. Increasing urban wage inequality in China: Extent, elements and evaluation. Economics of Transition 11(4), 597-619.

Li. H., 2003. Economic transition and returns to education in China. Economics of Education Review. 22(3), 317-328.

Li, H., Luo, Y., 2004. Reporting errors, ability heterogeneity, and returns to schooling in China. Pacific Economic Review. 9(3), 191-207.

Li, H., Liu, P., Ma, N., Zhang, J., 2005. Does education pay in urban China? Estimating returns to education using twins. City University of Hong Kong working paper, http://www.econ.cuhk.edu.hk/ discusspaper/00013.pdf

Liu, P., Meng, X., Zhang, J., 2000. Sectoral gender wage differentials and discrimination in the transitional Chinese economy. Journal of Population Economics, 13(2), 331-352.

Liu, Z., 1998. Earnings, education, and economic reforms in urban China. Economic Development and Cultural Change. 46(4), 697-725. 
Maurer-Fazio, M., 1999. Earnings and education in China’s transition to a market economy: survey evidence from 1989 and 1992. China Economic Review. 10(1), 17-40.

Mincer, J., 1974. Schooling, Experience and Earning. Columbia University Press: New York. Peng, X. 2011. China's Demographic History and Future Challenges. Science 333, 581-587. Psacharopoulos, G., Patrinos, H.A., 2004. Returns to investment in education: a further update. Education Economics. 12(2), 111 - 134

Rozelle, S., Dong, X., Zhang, L., Mason, A., 2002. Gender wage gaps in post-reform rural China. Pacific Economic Review. 7(1), 157-179.

Song, Y., 2012. Poverty reduction in China: The contribution of popularizing primary education. China \& World Economy. 20(1), 105-122.

Staiger, D., Stock, J.H., 1997. Instrumental variables regression with weak instruments. Econometrica. 65: 557-586.

Trostel, P., Walker, I., Woolley, P., 2002. Estimates of the economic return to schooling for 28 countries. Labor Economics, 9(1), 1-16.

Tsang, M.C., 1994. Costs of education in China: issues of resource mobilization, equality, equity, and efficiency. Education Economics. 2(3), 287-312.

------, 1996. Financial reform of basic education in China. Economics of Education Review. 15(4), 423-444.

------, 2000. Education and national development in China since 1949: Oscillating policies and enduring dilemmas. China Review. 579-618.

World Bank. 2011. China Overview. http://www.worldbank.org/en/country/china/overview (accessed on November 13, 2011).

Wu, X., Xie, Y., 2003. Does the market pay off? Earnings returns to education in urban China. American Sociological Review. 68(3), 425-442.

Yang, D.T., 2004. Education and allocative efficiency: household income growth during rural reforms in China. Journal of Development Economics,74, 137- 162. 
Yang, D.T., 2005. Determinants of schooling returns during transition: evidence from Chinese cities. Journal of Comparative Economics. 33(2), 244-264.

Zhang, X., Kanbur, R., 2005. Spatial inequality in education and health care in China. China Economic Review. 16(2), 189-204.

Zhang, J., Zhao, Y., Park, A., Song, X., 2005. Economic returns to schooling in urban China, 1988 to 2001. Journal of Comparative Economics. 33(4), 730-752.

Zhang, L., Huang, J. Rozelle, S., 2002. Employment, emerging labor markets, and the role of education in rural China. China Economic Review. 13, 313-328.

Zhou, X., 2000. Economic transformation and income inequality in urban China: Evidence from panel data. American Journal of Sociology, 105(4), 1135-1174. 
Table 1: Descriptive statistics

\begin{tabular}{|c|c|c|c|c|c|c|}
\hline $\begin{array}{l}\text { Variable }^{\mathrm{a}} \\
\text { Sample size }\end{array}$ & $\begin{array}{c}\text { All } \\
N=11271\end{array}$ & & $\begin{array}{c}\text { Control cohort } \\
N=7380\end{array}$ & & $\begin{array}{c}\text { Treatment cohort }^{b} \\
N=3891\end{array}$ & $P$ value ${ }^{c}$ \\
\hline Treatment $^{b}$ & 0.35 & & 0.00 & & 1.00 & N/A \\
\hline School years completed & 8.88 & & 8.66 & & 9.28 & $<0.01$ \\
\hline & ( 3.07 & ) & ( 3.17 & ) & ( 2.84 & \\
\hline $\begin{array}{l}\text { Yearly earnings in natural } \\
\text { log }\end{array}$ & 8.44 & & 8.56 & & 8.21 & $<0.01$ \\
\hline & ( 1.22 & ) & ( 1.09 & ) & ( 1.39 & \\
\hline Age & 31.83 & & 35.57 & & 24.74 & $<0.01$ \\
\hline & ( 7.12 & ) & ( 4.93 & ) & ( 4.88 & \\
\hline Male & 0.51 & & 0.50 & & 0.52 & 0.07 \\
\hline Race minority & 0.13 & & 0.12 & & 0.15 & $<0.01$ \\
\hline Married & 0.75 & & 0.90 & & 0.47 & $<0.01$ \\
\hline Urban & 0.25 & & 0.27 & & 0.21 & $<0.01$ \\
\hline Health status & & & & & & $<0.01$ \\
\hline Excellent & 0.19 & & 0.17 & & 0.24 & \\
\hline Good & 0.58 & & 0.58 & & 0.58 & \\
\hline Fair & 0.21 & & 0.22 & & 0.17 & \\
\hline Poor & 0.02 & & 0.02 & & 0.01 & \\
\hline Province & & & & & & $<0.01$ \\
\hline Heilongjiang & 0.14 & & 0.13 & & 0.15 & \\
\hline Liaoning & 0.07 & & 0.08 & & 0.07 & \\
\hline Jiangsu & 0.12 & & 0.12 & & 0.13 & \\
\hline Shandong & 0.09 & & 0.09 & & 0.11 & \\
\hline Henan & 0.11 & & 0.10 & & 0.14 & \\
\hline Hubei & 0.11 & & 0.12 & & 0.10 & \\
\hline Hunan & 0.09 & & 0.11 & & 0.05 & \\
\hline Guangxi & 0.13 & & 0.16 & & 0.08 & \\
\hline Guizhou & 0.13 & & 0.11 & & 0.16 & \\
\hline CHNS wave & & & & & & $<0.01$ \\
\hline 1997 & 0.27 & & 0.28 & & 0.26 & \\
\hline 2000 & 0.21 & & 0.22 & & 0.19 & \\
\hline 2004 & 0.26 & & 0.25 & & 0.28 & \\
\hline 2006 & 0.26 & & 0.25 & & 0.27 & \\
\hline
\end{tabular}

Data source: China Health and Nutrition Survey (CHNS) 1997, 2000, 2004, and 2006.

${ }^{a}$ Standard deviations are reported in parentheses for continuous variables.

${ }^{\mathrm{b}}$ The control cohort includes respondents that were not affected by the 1986 China Compulsory Education Law, and the treatment cohort includes respondents that were affected by the 1986 China Compulsory Education Law. The effective dates of the 1986 China Compulsory Education Law in the different provinces varied. We define the sample so that a treatment respondent was less than 15 years old on the law's effective date in the province where he or she lived, and a control respondent was 15 years or older on the effective date.

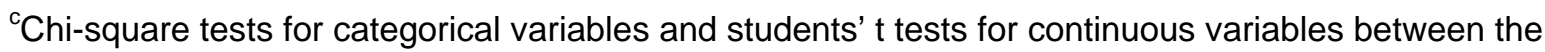
control cohort and treatment cohort.

N/A: not applicable. 
Table 2: The impact of the compulsory schooling law on years of schooling: Selected results from the first stage of the 2-stage least squares estimation (2SLS)

\begin{tabular}{|c|c|c|c|c|}
\hline \multirow[t]{2}{*}{ First stage estimation in 2SLS } & \multicolumn{4}{|c|}{ School years completed is the dependent variable (OLS coefficient) ${ }^{\mathrm{a}}$} \\
\hline & All & $\begin{array}{l}\text { Two-year control } \\
\text { and two-year } \\
\text { treatment cohort }\end{array}$ & $\begin{array}{l}\text { Two-year } \\
\text { control cohort }\end{array}$ & $\begin{array}{l}\text { Two-year } \\
\text { treatment cohort }\end{array}$ \\
\hline Age on the date the law was implemented & N/A & 13 - 16 years old & 15 - 16 years old & 13 - 14 years old \\
\hline \multicolumn{5}{|l|}{ Instrumental variable } \\
\hline $\begin{array}{l}\text { Less than } 15 \text { years old by the effective date } \\
\text { (Treatment dummy of compulsory education law) }\end{array}$ & $\begin{array}{l}0.79 * \star \star \\
(0.11)\end{array}$ & $\begin{array}{l}0.66^{\star \star \star} \\
(0.14)\end{array}$ & & \\
\hline $\begin{array}{l}\text { Less than } 16 \text { years old by the effective date } \\
\text { (Year dummy variable) }\end{array}$ & & & $\begin{array}{c}0.12 \\
(0.21)\end{array}$ & \\
\hline $\begin{array}{l}\text { Less than } 14 \text { years old by the effective date } \\
\text { (Year dummy variable) }\end{array}$ & & & & $\begin{array}{l}0.38 \star \star \\
(0.18)\end{array}$ \\
\hline \multicolumn{5}{|l|}{ Test of excluded instruments } \\
\hline F statistic & $54.78^{\star \star \star}$ & $21.85^{\star \star \star}$ & 0.33 & $4.23^{\star \star}$ \\
\hline \multicolumn{5}{|l|}{ Under-identification tests } \\
\hline Kleibergen-Paap rk LM statistic & $55.15^{\star \star \star}$ & $21.79 * \star \star$ & 0.33 & $4.28 * \star$ \\
\hline Kleibergen-Paap rk Wald statistic & $54.89 * \star *$ & $22.06^{\star \star \star}$ & 0.33 & $4.32^{\star \star}$ \\
\hline \multicolumn{5}{|l|}{ Weak identification test } \\
\hline Kleibegen-Paap Wald rk F statistic ${ }^{b}$ & $54.78^{\star}$ & $21.85^{\star}$ & 0.33 & 4.23 \\
\hline \multicolumn{5}{|l|}{ Weak-instrument-robust inference } \\
\hline Anderson-Rubin Wald test: F statistic & $10.69 * \star \star$ & $9.97 * \star \star$ & 0.41 & 0.03 \\
\hline Anderson-Rubin Wald test: Chi-square statistic & $10.71^{\star \star \star}$ & $10.07^{\star * *}$ & 0.40 & 0.03 \\
\hline Stock-Wright LM S statistic & $10.69 * \star \star$ & $9.98^{\star \star \star}$ & 0.40 & 0.03 \\
\hline $\begin{array}{l}\text { * significant at the } 10 \% \text { level; }{ }^{* *} \text { significant at the } 5 \% \\
\text { a All the estimations have controlled for other explana } \\
\text { b } 10 \% \text { maximal IV size as the Stock-Yogo weak ID te } \\
\text { Stock-Yogo (2005). } \\
\text { N/A: not anplicable }\end{array}$ & $\begin{array}{l}\text { evel; }{ }^{\star * *} \text { sig } \\
\text { ory variabl } \\
\text { c critical va }\end{array}$ & $\begin{array}{l}\text { ficant at the } 1 \% \text { lev } \\
\text { in Table } 1 . \\
\text { es is } 16.38, \text { and sm }\end{array}$ & naximal IV sizes & ot available in \\
\hline
\end{tabular}


Table 3: The impact of the compulsory schooling law by gender and location: Selected results of the first stage estimation in 2SLS for various sub-populations

\begin{tabular}{|c|c|c|c|c|c|c|}
\hline \multirow[t]{2}{*}{ First stage estimation in 2SLS } & \multicolumn{6}{|c|}{ School years completed is the dependent variable (OLS coefficient) ${ }^{a}$} \\
\hline & Female & Male & Rural & Urban & Inland & Coastal \\
\hline \multicolumn{7}{|l|}{ Instrumental variable } \\
\hline $\begin{array}{l}\text { Less than } 15 \text { years old by the effective date } \\
\text { (Treatment dummy of compulsory education law) }\end{array}$ & $\begin{array}{l}1.17^{\star \star \star} \\
(0.15)\end{array}$ & $\begin{array}{c}0.40^{\star \star \star} \\
(0.15)\end{array}$ & $\begin{array}{l}0.82^{\star \star \star} \\
(0.16)\end{array}$ & $\begin{array}{l}0.76^{\star \star \star} \\
(0.21)\end{array}$ & $\begin{array}{l}0.72^{\star \star \star} \\
(0.12)\end{array}$ & $\begin{array}{l}0.83^{\star \star \star} \\
(0.22)\end{array}$ \\
\hline \multicolumn{7}{|l|}{ Test of excluded instruments } \\
\hline F statistic & $59.84^{\star * *}$ & $7.36^{\star \star \star}$ & $45.96 * \star \star$ & $21.68^{\star \star *}$ & $35.02^{* * *}$ & $14.43^{* * *}$ \\
\hline \multicolumn{7}{|l|}{ Under-identification tests } \\
\hline Kleibergen-Paap rk LM statistic & $60.00 * * *$ & $7.43^{\star \star \star}$ & $46.26^{\star \star \star}$ & $12.91 * \star \star$ & $35.34^{\star \star \star}$ & $14.49^{\star \star \star}$ \\
\hline Kleibergen-Paap rk Wald statistic & $60.06^{\star * *}$ & $7.39^{\star * *}$ & $46.07^{\star \star *}$ & $12.78^{* * *}$ & $35.10^{\star * *}$ & $14.51^{\star \star \star}$ \\
\hline \multicolumn{7}{|l|}{ Weak identification test } \\
\hline Kleibegen-Paap Wald rk F statistic ${ }^{b}$ & $59.84^{*}$ & 7.36 & $45.96^{\star}$ & 12.68 & $35.02^{*}$ & 14.43 \\
\hline \multicolumn{7}{|l|}{ Weak-instrument-robust inference } \\
\hline Anderson-Rubin Wald test: F statistic & $3.33^{*}$ & $8.56^{\star \star \star}$ & $6.47^{\star * *}$ & 2.05 & 2.21 & $15.18^{\star \star \star}$ \\
\hline Anderson-Rubin Wald test: Chi-square statistic & $3.34^{*}$ & $8.59^{\star * *}$ & $6.48^{\star \star \star}$ & 2.06 & 2.22 & $15.26^{\star \star \star}$ \\
\hline Stock-Wright LM S statistic & $3.34^{*}$ & $8.54^{\star \star \star}$ & $6.47^{\star \star \star}$ & 2.06 & 2.22 & $15.01^{\star \star \star}$ \\
\hline
\end{tabular}

\footnotetext{
* significant at the $10 \%$ level; ** significant at the $5 \%$ level; *** significant at the $1 \%$ level.

${ }^{a}$ All estimations have controlled for the other explanatory variables in Table 1. Descriptive statistics for these subpopulations are given in the appendix table.

${ }^{\mathrm{b}} 10 \%$ maximal IV size as the Stock-Yogo weak ID test critical values is 16.38 , and smaller maximal IV sizes are not available in Stock-Yogo (2005)
} 
Table 4: Returns to schooling results by OLS and 2SLS for CHNS respondents born after 1961 (the “All” sample)

\begin{tabular}{|c|c|c|c|c|c|c|}
\hline \multirow[t]{2}{*}{ Variable } & \multicolumn{3}{|c|}{ OLS } & \multicolumn{3}{|c|}{$2 S L S$} \\
\hline & Coeff. & & S.E. & Coeff. & & S.E. \\
\hline School years completed & 0.09 & $\star * \star *$ & $(0.004)$ & 0.20 & 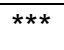 & $(0.06)$ \\
\hline Age & 0.25 & *** & $(0.02)$ & 0.22 & $\star \star \star *$ & $(0.02)$ \\
\hline Age squared & 0.00 & $\star \star *$ & $(0.0003)$ & 0.00 & $\star \star \star *$ & $(0.0003)$ \\
\hline Male & 0.21 & $\star \star \star *$ & $(0.02)$ & 0.15 & $\star \star \star *$ & $(0.04)$ \\
\hline Race minority & -0.12 & $\star \star *$ & $(0.05)$ & -0.09 & * & $(0.05)$ \\
\hline Married & -0.14 & *** & $(0.04)$ & -0.06 & & $(0.06)$ \\
\hline Urban & 0.19 & 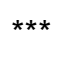 & $(0.03)$ & -0.10 & & $(0.16)$ \\
\hline $\begin{array}{l}\text { Health status } \\
\text { Excellent (reference) }\end{array}$ & & & & & & \\
\hline Good & -0.04 & & $(0.03)$ & -0.05 & & $(0.03)$ \\
\hline Fair & -0.15 & $* \star \star$ & $(0.04)$ & -0.14 & *** & $(0.04)$ \\
\hline Poor & -0.34 & $* * *$ & $(0.10)$ & -0.24 & ** & $(0.12)$ \\
\hline \multicolumn{7}{|l|}{ Province } \\
\hline \multicolumn{7}{|l|}{ Heilongjiang (reference) } \\
\hline Liaoning & 0.11 & $\star \star$ & $(0.06)$ & 0.03 & & $(0.07)$ \\
\hline Jiangsu & 0.50 & $* \star *$ & $(0.04)$ & 0.44 & $\star \star * *$ & $(0.05)$ \\
\hline Shandong & 0.14 & $\star \star \star *$ & $(0.05)$ & 0.11 & ** & $(0.05)$ \\
\hline Henan & -0.19 & $\star \star \star$ & (0.05) & -0.20 & $\star \star \star$ & $(0.05)$ \\
\hline Hubei & -0.17 & $\star * *$ & (0.05) & -0.16 & *** & $(0.05)$ \\
\hline Hunan & 0.02 & & (0.05) & -0.05 & & $(0.07)$ \\
\hline Guangxi & -0.04 & & $(0.05)$ & -0.02 & & $(0.05)$ \\
\hline Guizhou & -0.21 & $* * *$ & $(0.05)$ & -0.14 & ** & $(0.07)$ \\
\hline \multicolumn{7}{|l|}{ CHNS wave } \\
\hline \multicolumn{7}{|l|}{1997 (reference) } \\
\hline 2000 & -0.01 & & $(0.03)$ & -0.07 & & $(0.05)$ \\
\hline 2004 & 0.15 & $\star * *$ & (0.04) & 0.04 & & (0.08) \\
\hline 2006 & 0.43 & $* \star *$ & $(0.04)$ & 0.28 & $\star \star \star$ & $(0.10)$ \\
\hline Constant & 3.24 & $* \star \star$ & $(0.28)$ & 2.64 & $\star \star \star *$ & $(0.48)$ \\
\hline
\end{tabular}

* significant at the $10 \%$ level; ** significant at the $5 \%$ level; ${ }^{\star \star *}$ significant at the $1 \%$ level. 
Table 5: Robustness check on instrument

\begin{tabular}{|c|c|c|c|c|c|c|c|c|c|}
\hline \multirow{3}{*}{$\begin{array}{l}\text { Yearly earning in natural log } \\
\text { as the dependent variable } \\
\text { Age by the effective date }\end{array}$} & \multirow{2}{*}{\multicolumn{3}{|c|}{$\begin{array}{c}\text { Two-year control } \\
\text { and Two-year } \\
\text { treatment cohorts }\end{array}$}} & \multirow{2}{*}{\multicolumn{3}{|c|}{$\begin{array}{c}\begin{array}{c}\text { Two-year } \\
\text { control cohort }\end{array} \\
15 \text { - } 16 \text { years old }\end{array}$}} & \multirow{2}{*}{\multicolumn{3}{|c|}{$\begin{array}{c}\begin{array}{c}\text { Two-year } \\
\text { treatment cohort }\end{array} \\
13 \text { - } 14 \text { years old }\end{array}$}} \\
\hline & & & & & & & & & \\
\hline & Coeff. & & S.E. & Coeff. & & S.E. & Coeff. & & S.E. \\
\hline \multicolumn{10}{|l|}{ OLS } \\
\hline School years completed & 0.09 & *** & $(0.01)$ & 0.09 & $* * *$ & $(0.01)$ & 0.10 & *** & $(0.02)$ \\
\hline \multicolumn{10}{|l|}{$2 S L S^{b}$} \\
\hline School years completed & 0.26 & *** & $(0.09)$ & 0.54 & & (1.11) & 0.04 & & $(0.22)$ \\
\hline
\end{tabular}

* significant at the $10 \%$ level; ** significant at the $5 \%$ level; *** significant at the $1 \%$ level.

${ }^{a}$ All estimations have controlled for the other explanatory variables in Table 1.

${ }^{b}$ Using the instrumental variables as those in Table 3 for various study cohorts respectively. 
Table 6: Selected results by gender, urbanization, and province location (the “All” sample)

\begin{tabular}{|c|c|c|c|c|c|c|}
\hline \multirow{3}{*}{$\begin{array}{l}\text { The dependent variable is the annual income } \\
\text { in natural log }\end{array}$} & \multicolumn{6}{|c|}{ Coefficients on "School years completed" } \\
\hline & \multicolumn{3}{|c|}{ OLS } & \multicolumn{3}{|c|}{$2 S L S$} \\
\hline & Coeff. & & S.E. & Coeff. & & S.E. \\
\hline \multicolumn{7}{|l|}{ By gender } \\
\hline Female & 0.09 & 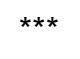 & $(0.01)$ & 0.10 & * & $(0.05)$ \\
\hline Male & 0.09 & *** & $(0.01)$ & 0.51 & ** & $(0.23)$ \\
\hline \multicolumn{7}{|l|}{ By urbanization } \\
\hline Rural & 0.09 & $\star * \star$ & $(0.01)$ & 0.18 & $\star \star \star *$ & $(0.07)$ \\
\hline Urban & 0.08 & *** & $(0.01)$ & 0.14 & & $(0.09)$ \\
\hline \multicolumn{7}{|l|}{ By province location } \\
\hline Inland provinces & 0.09 & *** & $(0.01)$ & 0.12 & & $(0.08)$ \\
\hline Coastal provinces & 0.09 & $\star \star \star$ & $(0.01)$ & 0.37 & $\star \star \star$ & $(0.12)$ \\
\hline
\end{tabular}

* significant at the $10 \%$ level; ${ }^{\star \star}$ significant at the $5 \%$ level; ${ }^{\star \star *}$ significant at the $1 \%$ level. 
Table 7: Selected results for the sensitivity analysis using “placebo” law years

\begin{tabular}{|c|c|c|}
\hline $\begin{array}{l}\text { School years completed is the dependent } \\
\text { variable }^{\mathrm{a}}\end{array}$ & $\begin{array}{l}\text { Four-year } \\
\text { control cohort } \\
\text { (cohort } 1 \text { and } \\
\text { cohort 2) }\end{array}$ & $\begin{array}{l}\text { Four-year } \\
\text { treatment cohort } \\
\text { (cohort } 3 \text { and } \\
\text { cohort 4) }\end{array}$ \\
\hline Age by the effective date & 15 - 18 years old & 11 - 14 years old \\
\hline \multicolumn{3}{|l|}{$\begin{array}{l}\text { The first stage estimation in 2SLS } \\
\text { Instrumental variable }\end{array}$} \\
\hline $\begin{array}{l}\text { Less than } 17 \text { years old by the effective date } \\
\text { (year dummy variable) }\end{array}$ & $\begin{array}{c}0.21 \\
(0.14)\end{array}$ & \\
\hline $\begin{array}{l}\text { Less than } 13 \text { years old by the effective date } \\
\text { (year dummy variable) }\end{array}$ & & $\begin{array}{l}0.25^{\star} \\
(0.14)\end{array}$ \\
\hline \multicolumn{3}{|l|}{ Test of excluded instruments } \\
\hline F statistic & 2.28 & $3.64^{*}$ \\
\hline \multicolumn{3}{|l|}{ Under-identification tests } \\
\hline Kleibergen-Paap rk LM statistic & 2.29 & $3.66^{*}$ \\
\hline Kleibergen-Paap rk Wald statistic & 2.3 & $3.68^{*}$ \\
\hline \multicolumn{3}{|l|}{ Weak identification test } \\
\hline Kleibegen-Paap Wald rk F statistic ${ }^{b}$ & 2.28 & 3.64 \\
\hline \multicolumn{3}{|l|}{ Weak-instrument-robust inference } \\
\hline Anderson-Rubin Wald test: F statistic & $3.10^{\star}$ & $2.90 *$ \\
\hline Anderson-Rubin Wald test: Chi-square statistic & $3.13^{*}$ & $2.93^{\star}$ \\
\hline Stock-Wright LM S statistic & $3.13^{*}$ & $2.93^{*}$ \\
\hline \multicolumn{3}{|l|}{ The second stage estimation in 2 SLS } \\
\hline \multirow{2}{*}{ School years completed } & 0.44 & 0.43 \\
\hline & $(0.33)$ & $(0.29)$ \\
\hline
\end{tabular}

* significant at the 10\% level; ** significant at the 5\% level; *** significant at the $1 \%$ level.

${ }^{a}$ All estimations have controlled for the other explanatory variables in Table 1.

${ }^{\mathrm{b}} 10 \%$ maximal IV size as the Stock-Yogo weak ID test critical values is 16.38 , and smaller maximal IV sizes are not available in Stock-Yogo (2005). 
Appendix: Descriptive statistics by sub-populations

\begin{tabular}{|c|c|c|c|c|c|c|c|c|c|c|c|}
\hline $\begin{array}{l}\text { Variable } \\
\text { Sample size }\end{array}$ & $\begin{array}{l}\text { Female } \\
\mathrm{N}=5574\end{array}$ & & $\begin{array}{r}\text { Male } \\
\mathrm{N}=5697\end{array}$ & & $\begin{array}{r}\text { Rural } \\
\mathrm{N}=8468\end{array}$ & & $\begin{array}{r}\text { Urban } \\
\mathrm{N}=2803\end{array}$ & & $\begin{array}{r}\text { Inland } \\
\mathrm{N}=7994\end{array}$ & & $\begin{array}{l}\text { Coastal } \\
\mathrm{N}=3277\end{array}$ \\
\hline Treatment $^{\mathrm{a}}$ & 0.34 & & 0.35 & & 0.36 & & 0.29 & & 0.34 & & 0.36 \\
\hline \multirow[t]{2}{*}{ Yearly earning in natural log } & 8.32 & & 8.56 & & 8.29 & & 8.88 & & 8.29 & & 8.79 \\
\hline & ( 1.18 & ) & $(1.24$ & ) & $(1.27$ & ) & $(0.90$ & ) & $(1.23$ & ) & ( 1.11 \\
\hline \multirow[t]{2}{*}{ School years completed } & 8.46 & & 9.29 & & 8.14 & & 11.09 & & 8.73 & & 9.24 \\
\hline & ( 3.27 & ) & ( 2.81 & ) & ( 2.84 & ) & ( 2.67 & ) & ( 2.99 & ) & $(3.23$ \\
\hline \multirow[t]{2}{*}{ Age } & ( 32.12 & ) & ( 31.54 & ) & ( 31.36 & ) & ( 33.23 & ) & $(31.45$ & ) & ( 32.74 \\
\hline & 7.04 & & 7.18 & & 7.25 & & 6.51 & & 7.16 & & 6.94 \\
\hline Male & 0.00 & & 1.00 & & 0.51 & & 0.51 & & 0.51 & & 0.49 \\
\hline Race minority & 0.13 & & 0.13 & & 0.14 & & 0.09 & & 0.15 & & 0.08 \\
\hline Married & 0.79 & & 0.71 & & 0.75 & & 0.76 & & 0.74 & & 0.78 \\
\hline Urban & 0.25 & & 0.25 & & 0.00 & & 1.00 & & 0.25 & & 0.24 \\
\hline \multicolumn{12}{|l|}{ Health status } \\
\hline Excellent & 0.16 & & 0.22 & & 0.18 & & 0.23 & & 0.16 & & 0.27 \\
\hline Good & 0.58 & & 0.58 & & 0.59 & & 0.56 & & 0.59 & & 0.55 \\
\hline Fair & 0.23 & & 0.18 & & 0.21 & & 0.19 & & 0.22 & & 0.17 \\
\hline Poor & 0.02 & & 0.02 & & 0.02 & & 0.01 & & 0.02 & & 0.01 \\
\hline \multicolumn{12}{|l|}{ Province } \\
\hline Heilongjiang & 0.13 & & 0.14 & & 0.13 & & 0.15 & & 0.19 & & 0.00 \\
\hline Liaoning & 0.08 & & 0.07 & & 0.08 & & 0.06 & & 0.00 & & 0.25 \\
\hline Jiangsu & 0.13 & & 0.11 & & 0.12 & & 0.13 & & 0.00 & & 0.42 \\
\hline Shandong & 0.09 & & 0.09 & & 0.09 & & 0.10 & & 0.00 & & 0.32 \\
\hline Henan & 0.11 & & 0.12 & & 0.11 & & 0.12 & & 0.16 & & 0.00 \\
\hline Hubei & 0.12 & & 0.11 & & 0.11 & & 0.12 & & 0.16 & & 0.00 \\
\hline Hunan & 0.09 & & 0.09 & & 0.08 & & 0.11 & & 0.13 & & 0.00 \\
\hline Guangxi & 0.13 & & 0.13 & & 0.14 & & 0.10 & & 0.18 & & 0.00 \\
\hline Guizhou & 0.12 & & 0.13 & & 0.13 & & 0.11 & & 0.18 & & 0.00 \\
\hline \multicolumn{12}{|l|}{ CHNS wave } \\
\hline 1997 & 0.27 & & 0.28 & & 0.28 & & 0.25 & & 0.29 & & 0.21 \\
\hline 2000 & 0.20 & & 0.22 & & 0.22 & & 0.20 & & 0.21 & & 0.22 \\
\hline 2004 & 0.26 & & 0.25 & & 0.26 & & 0.27 & & 0.25 & & 0.28 \\
\hline 2006 & 0.27 & & 0.25 & & 0.25 & & 0.28 & & 0.25 & & 0.29 \\
\hline
\end{tabular}


${ }^{a}$ The control cohort includes respondents that were not affected by the 1986 China Compulsory Education Law, and the treatment cohort includes respondents that were affected by the 1986 China Compulsory Education Law. The effective dates of the 1986

China Compulsory Education Law in the different provinces varied. We define the sample so that a treatment respondent was less than 15 years old on the law's effective date in the province where he or she lived, and a control respondent was 15 years or older on the effective date. 